\title{
Persepsi Guru terhadap Pembelajaran Tatap Muka Terbatas di SD se-Gugus I Salawati Kabupaten Sorong
}

\author{
Risza Tri Fatmawati Widianingrum ${ }^{1}, \operatorname{Asrul}^{2} \&$ Mustika Irianti $^{3}$ \\ Prodi PGSD, Universitas Pendidikan Muhammadiyah Sorong, Indonesia \\ ${ }^{\otimes}$ E-mail: riszatri14@gmail.com
}

\begin{abstract}
Abstrak
Penelitian ini dilakukan dengan tujuan menganalisis Persepsi Guru Terhadap Pembelajaran Tatap Muka Terbatas Muatan IPA Pada Sekolah Dasar Gugus I Salawati Kabupaten Sorong. Penelitian ini menggunakan metode kualitataif, dengan pendekatan studi kasus. Teknik pengumpulan data yaitu observasi, wawancara dan studi dokumentasi. Subjek penelitian adalah guru kelas V di Gugus I Salawati Kabupaten Sorong. Analisis data yang digunakan dalam penelitian ini meliputi reduksi data, penyajian data dan kesimpulan atau verifikasi. Hasil penelitian menunjukkan bahwa persepsi guru terhadap pembelajaran tatap muka terbatas (PTMt), yaitu: 1. Kebijakan, pelaksanaan PTMt dapat dilaksanakan sesuai kebijakan pemerintah melalui SKB 4 menteri dan surat edaran bupati Sorong dengan sistem blok atau shieft. 2. Perencanaan, perencanaan PTMt disesuaikan dengan kondisi dan durasi yang sudah ditetapkan. 3. Pelaksanaan, cakupan materi dalam pelaksanaan PTMt terutama pada muatan IPA disampaikan sesederhana mungkin agar tidak memberatkan siswa. 4. Evaluasi, disesuaikan dengan kondisi yang ada serta dilakukan setelah peserta didik mengumpulkan tugas yang sudah diberikan baik itu teori maupun praktek. Kesimpulan dari penelitian ini bahwa PTMt lebih efektif dilakukan dimasa pandemi dibanding pembelajaran secara daring, kegiatan PTMt berlangsung normal meski ketersediaan waktu yang terbatas sesuai aturan pemeritah.
\end{abstract}

Kata Kunci: Persepsi Guru; PTMt; Muatan IPA;

\begin{abstract}
This study uses a qualitative method, with a case study approach. Data collection techniques are observation, interviews and documentation studies. The research subjects were fifth grade teachers in Cluster I Salawati, Sorong Regency. Data analysis used in this study includes data reduction, data presentation and conclusions or levers. The results showed that teachers' perceptions of face-to-face learning were limited (PTMt), namely: 1. Policy, The implementation of PTMt could be implemented according to government policy through a 4 ministerial decree and a circular letter from the regent of Sorong with a block or shift system. 2. Planning, PTMt planning is adjusted to the conditions and duration that have been set. 3. Implementation, the scope of material in the implementation of PTMt, especially the science content, is delivered as simply as possible so as not to burden students. 4. Evaluation, adapted to exising conditions and carried out after students collect the tasks that have been given both theory and practice. Based on the results interviews conducted, it can be concluded that PTMt is more effevtive during a pandemic than online learning, PTMt activities take place normally even though the availability of time is limited according to government regulations.
\end{abstract}

Keywords: Teacher's Perception; PTMt; Science Conten; 


\section{PENDAHULUAN}

Pembelajaran adalah pemberdayaan potensi peserta didik menjadi kompetensi. Kegiatan pemberdayaan ini tidak dapat berhasil tanpa adanya kerja sama setiap individu (pendidik, peserta didik, masyarakat). Menurut Dimyati dan Mudjito dalam (Sagala, 2011) menyatakan bahwa pembelajaran adalah kegiatan pendidik secara terprogram dalam desain intruksional, untuk membuat belajar aktif, yang menekankan pada penyediaan sumber belajar.

Pembelajaran merupakan salah satu proses panjang untuk mencapai hasil yang lebih. Adanya pencapaian hasil yang lebih maka diperlukan strategi yang tepat. Strategi pembelajaran merupakan suatu cara yang dilakukan oleh pendidik terhadap peserta didik dalam mengupayakan terjadinya perubahan aspek kognitif, afektif, dan motorik yang terjalin secara berkesinambungan (Sobron, et.al, 2020). Strategi pembelajaran sangat penting dilakukan oleh pendidik, hal ini berkaitan dengan proses pembelajaran yang sedang menjadi perhatian di masa pandemik seperti saat ini.

Saat ini sedang meningkatnya wabah Corona Virus atau COVID-19. Corona virus merupakan keluarga besar virus yang menyebabkan penyakit pada manusia dan hewan. Virus yang menyerang manusia biasanya menyebabkan penyakit infeksi pada saluran pernapasan, mulai flu biasa hingga penyakit yang serius seperti Middle East Respiratory Syndrome (MERS) dan Sindrom Pernapasan Akut Berat/ Severe Acute Respiratory Syndrome (SARS) (Pakpahan, R. \& Fitriani, Y. 2020).

Adanya wabah Covid-19 yang semakin meluas pada tanggal 24 Maret 2020 Mentri Pendidikan dan Kebudayaan Republik
Indonesia mengeluarkan Surat Edaran Nomor 4 Tahun 2020 Tentang Pelaksanaan Kebijakan Pendidikan Dalam Masa Darurat Penyebaran COVID, dalam Surat Edaran tersebut dijelaskan bahwa proses pembelajaran dilaksanakan di rumah melalui pembelajaran daring/jarak jauh dilaksanakan untuk memberikan pengalaman belajar yang bermakna bagi siswa. Belajar di rumah dapat difokuskan pada pendidikan kecakapan hidup antara lain mengenai pandemi covid-19 (Mendikbud, 2020).

Kebijakan belajar dari rumah memberikan banyak spekulasi dari berbagai pihak, salah satunya para guru. Guru diharuskan tetap menyampaikan materi pembelajaran walaupun prosesnya tidak terjadi secara langsung (Daring). Pembelajaran daring atau online bertujuan untuk memenuhi standart pendidikan dengan pemanfaatan Teknologi Informasi dengan menggunakan perangkat komputer atau gadget yang saling terhubung antar guru dan siswa. Pemanfaatan teknologi tersebut membantu berjalannya proses belajar mengajar dapat tetap dilaksanakan dengan baik (Pakpahan, R. \& Fitriani, Y. 2020).

Pembelajaran daring memberikan kesempatan peserta didik belajar dengan keleluasaan waktu belajar serta dimanapun dan kapanpun peserta didik dan guru berada. Perserta didik dapat berinteraksi dengan guru dengan menggunakan beberapa aplikasi seperti classroom, video converence, telpon atau live chat, zoom maupun melalui whatsapp group (Assidiqi \& Sumami, 2020). Pembelajaran daring menjadi solusi dimasa pandemi COVID-19. Melalui penerapan kebijakan pembelajaran jarak jauh ini diharapkan dunia pendidikan turut serta mendukung pemerintah dalam menekan laju penyebaran Covid-19 sehingga pendidikan di Indonesia dapat terus berlangsung. Akan 
tetapi pembelajaran daring tidak mudah seperti yang dibayangkan. Hal ini berkaitan dengan beberapa faktor seperti: akses jaringan terbatas, masih banyak peserta didik yang tidak memiliki smartphone, gagap teknologi, dan adanya keterhambatan biaya yang harus disiapkan untuk membeli kuota internet.

Pembelajaran daring telah berlangsung kurang lebih 1 tahun, dan Covid-19 yang terus menerus ditekan penyebarannya. Penekanan penyebaran Covid-19 dengan cara menjaga jarak, tetap hidup bersih, mencuci tangan (5M), mengkonsumsi makanan sehat, pembatasan kegiatan masyarakat (PKM) dan adanya vaksin yang sedang dilakukan secara bertahap. Hal ini diharapkan agar penyebaran Covid-19 semakin menurun sehingga kegiatan masyarakat dapat kembali normal, seperti kembali ke sekolah. Pembelajaran yang dilakukan secara daring telah berlangsung sekitar 3 semester, hal ini tidak mudah dilakukan bagi sekolah-sekolah yang berada didaerah yang tertinggal, terdepan, dan terluar.

Berdasarkan hasil kunjungan Menteri Pendidikan dan Kebudayaan Nadiem Makarim ke Sorong, Papua Barat pada Kamis 11 Februari 2021 menegaskan bahwa berdasarkan Surat Keputusan Bersama (SKB) yang dikeluarkan oleh pemerintah pusat. Melalui SKB itu Menteri melakukan penyesuaian kebijakan untuk memberikan kewenangan kepada pemerintah daerah, Kanwil atau Kemenag dalam menentukan pemberian izin tatap muka untuk sekolahsekolah di bawah kewenangannya dengan syarat tidak lebih dari 50 persen kapasitas dan tetap menerapka protokol kesehatan (Mega Wati, 2021). Hal tersebut di dukung dengan dikeluarkannya Surat Edaran Nomor: 412/143 Tentang Perubahan Surat Edaran Bupati Sorong Nomor 421/015 Tetang
Kegiatan Belajar Mengajar Semester Genap (Januari-Juni 2021) pada tanggal 16 Februari 2021. Surat tersebut berisi karena keterbatasan pembelajaran daring, maka untuk daerah timur seperti di Papua Barat mulai 22 Februari 2021 beberapa sekolah dapat melakukan pembelajaran tatap muka terbatas sesuai dengan zonanya.

Pembelajaran terlaksana secara tatap muka dilakukan secara terbatas. Hal ini memberikan sedikit udara segar bagi pendidik dan peserta didik. Pembelajaran tatap muka terbatas yang dilakukan di daerah timur seperti yang ada di Sorong Papua Barat dilakukan dengan berbagai strategi pembelajaran. Pembelajaran tatap muka terbatas memudahkan guru dan peserta didik untuk berinteraksi menyampaikan materi pelajaran. Guru dapat menyampaikan pelajaran lebih efektif, salah satunya pada muatan IPA. Pembelajaran tematik yang diterapkan di sekolah memerlukan berbagai macam strategi untuk menyampaikan materi secara efesien. Muatan IPA merupakan pembelajaran yang memerlukan pemahaman teori dan praktik.

Berdasarkan hasil observasi sekolah Gugus I Salawati Kabupaten Sorong, yang telah melakukan pembelajaran tatap muka terbatas menyatakan bahwa adanya pembelajaran yang telah kembali dilakukan secara tatap muka memudahkan guru untuk menyampaikan pelajaran. Pembelajaran tatap muka walaupun masih terbatas memberikan semangat baru bagi guru untuk memberikan pelajaran, memudahkan penyampaian materi tepatnya Muatan IPA, serta memperbaiki konsep materi pelajaran pada siswa, hal ini karena terdapat beberapa siswa yang tidak memahami materi yang disampaikan ketika pelajaran secara daring/online. Namun, adanya pelajaran tatap muka terbatas ini masih terdapat beberapa kekurangan seperti; 
terdapat peserta didik yang terkadang tertukar mata pelajaran, pembagian kelas yang masih membingungkan siswa, guru masih kelelahan karena harus menyampaikan materi yang sama pada satu hari dikelas yang berbeda, dan guru masih merasa kesusahan dalam memaksimalkan alokasi waktu.

\section{METODE PENELITIAN}

Penelitian ini menggunakan penelitian kualitatif dengan jenis penelitian wawancara terpusat (focused interviews), Penelitian kualitatif sebagai prosedur penelitian yang menghasilkan data deskriptif berupa katakata dan bahasa. Metode penelitian kualitatif dapat diartikan sebagai jenis penelitian yang berlandaskan pada filsafat postpositivisme, digunakan untuk meneliti pada kondisi obyek yang alamiah yaitu sebagai lawan dari eksperimen yang dimana peneliti sebagai peneliti kunci, teknik data yang dilakukan secara tringulasi (gabungan), analisis data bersifat induktif/kualitatif, dan hasil penelitian kualitatif lebih menekankan makna dari pada generalisasi (Sugiono, 2016).

Informan tersebut terdiri dari 4 guru/wali kelas $\mathrm{V}$ yaitu SD Inpres 44 Kabupaten Sorong, SD Inpres 46 Kabupaten Sorong, SD Inpres 35 Kabupaten Sorong dan SD Muhammadiyah Majaran Kabupaten Sorong. Penelitian ini menggunakan teknik pengumpulan data observasi, wawancara dan studi dokumentasi.

\section{HASIL DAN PEMBAHASAN}

Anak MS memiliki jenis ketunaan anak lamban belajar. Anak lamban belajar dikenal dengan istilah slow learners, backward, dull, atau borderline. Mumpuniarti (2007: 14) mengidentifikasi anak lamban belajar sebagai anak yang mempunyai IQ di antara 70 sampai 89.

Aspek yang menjadi kajian dalam penelitian ini yaitu persepsi guru mengenai pembelajaran tatap muka terbatas yang dilaksanakan selama pandemi Covid-19. Analisis data penelitian ini meliputi reduksi data, penyajian data, kesimpulan dan verifikasi data.

Adapun persepsi pembelajaran tatap muka terbatas yang berlangsung di SD Gugus I Salawati sebagai berikut:

Wawancara responden (SK) SD Inpres 35 Kabupaten Sorong

Peneliti mewawancarai guru/wali kelas (SK) dengan pertanyaan-pertanyaan yang berkaitan dengan persepsi pembelajaran tatap muka terbatas sebagai berikut:

Tabel 1. Daftar Pertanyaan SD Inpres 35 Kabupaten Sorong

Pertanyaan 1

\begin{tabular}{ll}
\hline Peneliti & : Bagaimana implementasi \\
& pembelajaran tatap muka \\
& terbatas di masa pandemic \\
& Covid-19 yang diterapkan \\
& disekolah?
\end{tabular}

Responden : Alhamdulillah bisa dijalankan sesuai dengan anjuran pemerintah, di sekolah ini dilaksanankan dengan sistem blok. Sistem blok ini dengan cara membagi siswa dalam 2 waktu yang berbeda. Contohnya siswa kelas V terdapat 30 siswa, dari 30 siswa tersebut dibagi menjadi 2, maka masing-masing kelompok ada 15 siswa. Proses pembelajaran ini menggunakan 2 waktu yang berbeda dalam 1 hari. Siswa pada kelompok 1 masuk pada pukul 08.00 wit dan pulang pada pukul 09.30 wit, kemudian siswa dari kelompok 2 masuk mulai pukul 09.30 wit -11.00 wit. Hal ini untuk mengurangi kerumunan atau saling bedesakan ketika berada di dalam 1 ruangan yang sama (kelas).

Pertanyaan ke 2

Peneliti : Apakah sudah membuat RPP sebelum

pembelajaran 
berlangsung?

Responden : Sudah. RPP yang satu lembar. Isinya kami sesuaikan dengan keadaan yang ada

Pertanyaan ke 3

Peneliti : Selama sistem pembelajaran tatap muka terbatas, Bagaimana cakupan materi IPA yang diimplementasikan pada siswa?

Responden : Karena pembelajaran tatap muka terbatas, maka materi yang disampaikan belum begitu maksimal. Materi IPA yang disampaikan ini lebih kearah teoritis, sedangkan untuk prakteknya tidak semua materi IPA dapat diterapkan. Akan tetapi untuk meninjau hal tersebut, guru memberikan contoh praktikum yang ada di internet (Youtube) untuk dapat diikuti siswa dengan cara mempraktekkannya di rumah.

Pertanyaan ke 4

Peneliti : Apa saja kendala yang dihadapi selama pembelajaran tatap muka terbatas pada muatan IPA ?

Responden : Banyak kendala yang dialami oleh para guru, hal ini pastinya juga dirasakan oleh siswa siswi, karena banyak materi yang belum tuntas. Sehingga untuk materi yang belum tuntas kami sampaikan secara daring (online)

Pertanyaan ke 5 melalui e-learning

Peneliti : Bagaimana sistem penilaian yang dilakukan oleh guru selama PTMt?

Responden : Penilaiannya setiap hari, karena tatap muka jadi setiap selesai pengumpulan tugas kami adakan penilaian.

Wawancara responden (SS) SD Inpres 44 Kabupaten Sorong

Peneliti mewawancarai guru/wali kelas

(SS) dengan pertanyaan-pertanyaan yang berkaitan dengan persepsi pembelajaran tatap muka terbatas sebagai berikut:

Tabel 2. Daftar Pertanyaan SD Inpres 44 Kabupaten Sorong

Pertanyaan ke 1

Peneliti

: Bagaimana implementasi pembelajaran tatap muka terbatas di masa pandemi Covid-19 yang diterapkan disekolah ?

\section{Responden}

Pertanyaan ke-2

Peneliti

Responden

Pertanyaan ke-3

Peneliti

Responden
: untuk PTMt bisa dijalankan sesuai dengan anjuran pemerintah, dengan sistem block. Sistem blok dengan cara membagi siswa dalam 2 waktu yang berbeda. Hal ini untuk mengurangi kerumunan atau saling berdesakan ketika siswa berada di dalam satu ruangan yang sama (kelas).

: Apakah sudah membuat RPP sebelum pembelajaran berlangsung?

: Sudah, sebelum tatap muka guru sudah menyiapkannya RPP untuk pembelajaran esok hari. Yang mana isinya kami sesuaikan dengan batas waktu yang tersedia sesuai dengan aturan PTMt.

: Selama sistem pembelajaran tatap muka terbatas,

Bagaimana cakupan materi IPA yang diimplementasikan pada siswa?

: memang pada saat PTMt ini pasti tidak semua materi dapat tersampaikan dengan maksimal. Namun sebagai guru, kita harus lebih kreatif dalam menyampaikan materi IPA contohnya, guru memberikan Modul di hari senin mengenai proses mencangkok. Pada hari senin tersebut siswa diberikan penjelasan singkat mengenai proses mencangkok, nah siswa bisa mempraktekkannya di rumah masing-masing. Ketika siswa melakukan pencangkokan pada tanaman pilihannya, maka siswa bisa membuat video proses pencangkokan. Hal tersebut nantinya akan membuat siswa lebih senang dalam belajar walapun tidak dilakukan 
Pertanyaan ke-4

Peneliti

Pertanyaan ke-5

Responden

Peneliti

Responden disekolah bersama guru dan teman kelasnya.

Apa saja kendala yang dihadapi selama pembelajaran tatap muka terbatas pada muatan IPA ?

: Nah ya itu tadi, berkaitan dengan waktu yang singkat. Sehingga materi yang disampaikan belum maksimal. Namun, semua itu kembali kepada guru yang harus lebih aktif ketika PTMt berlangsung.

: Bagaimana sistem penilaian yang dilakukan oleh guru selama PTMt?

: Penilaian dilaksanakan secara langsung (test lisan) dan secara tertulis (pemberian tugas)

\section{Wawancara responden (Kr) SD Inpres 46 Kabupaten Sorong}

Peneliti mewawancarai guru/wali kelas

(Kr) dengan pertanyaan-pertanyaan yang berkaitan dengan persepsi pembelajaran tatap muka terbatas sebagai berikut:

Tabel 3. Daftar Pertanyaan SD Inpres 46 Kabupaten Sorong

Pertanyaan ke-1

\begin{tabular}{ll}
\hline Peneliti & \multicolumn{1}{c}{ Bagaimana implementasi } \\
& pembelajaran tatap muka \\
& terbatas di masa pandemi \\
& Covid-19 yang diterapkan \\
& disekolah?
\end{tabular}

Responden : Kami menyesuaikan dengan waktu dan keadaan yang ada selama pembelajaran tatap muka terbatas, hal ini karena siswa dibatasi dalam lingkup ruang pembelajaran. Pembatasan ini dilakukan untuk menghindari adanya kerumunan selama proses pembelajaran di sekolah. Teknis yang diterapakan selama PTMt yaitu kami buat 2 kelompok dalam satu kelas, hal ini disesuaikan dengan waktu yang telah ditentukan oleh surat edaran dari Bupati Sorong nomor 421.7/801 mengenai pelaksanaan pembelajaran PTMt. Pembelajaran tatap muka terbatas, diatur dengan sistem block atau sistem Shieft dengan durasi waktu PTMt selama 3 jam (dimulai pada pukul 08.00 WIT - 11.00 WIT).

Pertanyaan ke-2

Peneliti : Apakah sudah membuat RPP sebelum pembelajaran berlangsung?

Responden : Tentu sudah walaupun hanya kegiatan inti yang singkat, karena kembali menyesuaikan waktu yang sudah ditentukan dalam PTMt.

Pertanyaan ke-3

Peneliti : Selama sistem pembelajaran tatap muka terbatas, Bagaimana cakupan materi IPA yang diimplementasikan pada siswa?

Responden : untuk muatan IPA kami tetap memberikan praktek, akan tetapi praktek yang disampaikan atau harus dilakukan oleh siswa adalah praktek yang mudah dikerjakan dirumah. Ketika disekolah guru hanya cukup mempraktekkannya didepan siswa, selanjutnya guru memberikan LKPD atau langkah-langkah praktikum. Lembar yang diterima oleh siswa itu, nantinya akan dijadikan acuan oleh siswa untuk mengerjakan praktikum sesuai dengan contoh yang telah dipaparkan oleh guru disekolah.

Pertanyaan ke-4

Peneiti : Apa saja kendala yang dihadapi selama pembelajaran tatap muka terbatas pada muatan IPA ?

Responden : Kendala yang dihadapi, yang pertama mengenai Waktu: karena sangat singkat, sehingga kita tidak bisa bertemu setiap hari dalam satu minggu. Hal ini untuk mengurangi resiko terpapar Covid-19. Kemudian 
yang kedua kita mengacu pada surat edaran yang telah kami terima, sehingga kami pun juga harus mengikuti peraturan yang telah ditetapkan. Selanjutnya sarana dan prasarana yang belum memadai, berkaitan dengn leptop dan pulsa, sehingga menjadi kendala. Contohnya ketika guru memberikan tugas mengguankan platform, terdapat siswa yang tidak mengumpulkan tugas dengan alasan tidak memiliki kuota. Selain itu untuk pengunaan smartphone, contohnya dalam 1 keluarga terdapat 4 orang anak, ketika semuanya secara tidak sengaja sedang daring dari rumah, sedangkan smartphone yang dimiliki hanya satu. Maka hal tersebut juga menjadi kendala, karena tidak semua keluarga memiliki pendapatan yang lebih untuk memberikan satu persatu anaknya samrtphone.

Pertanyaan ke-5

Peneliti : Bagaimana sistem penilaian yang dilakukan oleh guru selama PTMt?

Responden : Penilaiannya kami lakukan secara teori dan praktek, penilaiannya kami sesuaikan dengan situasi dan kondisi yang ada. Walupun ketercapaiannya tidak maksimal akibat pandemi.

Wawancara responden (IA) SD Muhammadiyah Majaran Kab. Sorong

Peneliti mewawancarai guru/wali kelas

(IA) dengan pertanyaan-pertanyaan yang berkaitan dengan persepsi pembelajaran tatap muka terbatas sebagai berikut:

Tabel 4. Daftar Pertanyaan SD Muhammadiyah Majaran Kab Sorong

Pertanyaan ke-1

Peneliti : Bagaimana implementasi

pembelajaran tatap muka

terbatas di masa pandemi
Covid-19 yang diterapkan disekolah?

Responden : Untuk implementasi tatap muka terbatas kami tidak melakukan sistem shieft berhubung siswa di sekolah kami sedikit. Untuk pelaksanaannya saya beri tugas kepada siswa dan memberikan sedikit penjelasan mengenai materi yang berkaitan dengan tugas tersebut. Kami juga sesuaikan dengan kondisi dan keadaan yang ada

Pertanyaan ke-2

Peneliti : Apakah sudah membuat RPP sebelum pembelajaran berlangsung?

Responden : Iya, selalu disiapkan. Jadi sebelum masuk kedalam kelas kami sudah mempersiapkannya. RPPnya kami sesuaikan dengan ketentuan PTMt.

Pertanyaan ke-3

Peneliti : Selama sistem pembelajaran tatap muka terbatas, Bagaimana cakupan materi IPA yang diimplementasikan pada siswa?

Responden : Cakupan materi IPA yang diterapkan menggunakan modul yang sudah dirancang khusus untuk PTMt, akan tetapi kami padukan dengan MBP yang sudah kami gunakan sebelum pandemi covid-19. Selain itu, kami biasanya mengambil contoh video pembelajaran yang ada di Youtube untuk memudahkan siswa dalam memahami materi yang sedang dipelajari.

Pertanyaan ke-4

Peneliti : Apa saja kendala yang dihadapi selama pembelajaran tatap muka terbatas pada muatan IPA

Responden : Kendala pada saat PTMt ini lebih ke waktu, karena dibatasi sesuai dengan peraturan yang berlaku. Jadi ketika kita mengajarkan materi kepada siswa, tidak bisa seperti biasanya yang memiliki waktu lebih banyak. Akan tetapi kita bisa menggunakan modul yang sudah kami 
Pertanyaan ke-5

sediakan dan juga bantuan dari platform yang ada seperti Youtube, google meet dll. Hal ini untuk membatu siswa belajara ketika di rumah.

Peneliti

Responden

Bagaimana sistem penilaian yang dilakukan oleh guru selama PTMt?

: Penilaiannya kami lakukan setelah pengumpulan tugas.

Berdasarkan data yang diperoleh dari wawancara mengenai persepsi pembelajaran tatap muka terbatas di SD Gugus I Salawati, maka data ditampilkan sebagai berikut.

\section{Responden (SK) SD Inpres 35 Kabupaten Sorong}

Hasil wawancara dengan responden (SK) mengenai persepsi guru tentang implementasi pembelajaran tatap muka terbatas di SD Inpres 35 Kabupaten Sorong menyatakan bahwa pembelajaran PTMt dilaksanakan sesuai dengan anjuran pemerintah menggunakan sistem blok. Sistem blok ini dengan cara membagi peserta didik dalam dua kelompok yang berbeda. Langkah ini dilakukan untuk mengurangi adanya kerumunan peserta didik, namun proses pembelajaran tetap berlangsung. Selain itu agar peserta didik yang berada didalam kelas tidak berdasak-desakan. Sedangkan perencanaan pembelajaran seperti RPP dan bahan ajar disiapkan sesuai dengan kebutuhan dan keadaan yang ada, hal ini dikarenakan waktu dalam PTMt cukup terbatas.

Persepsi responden (SK) SD Inpres 35 Kabupaten Sorong mengenai cakupan materi IPA selama PTMt disampaikan lebih kearah teoritis, dibandingkan dengan prakteknya. Hal ini karena tidak semua materi IPA dapat diterapkan seperti pembelajaran sebelumnya. Akibatnya materi IPA yang disampaikan belum begitu maksimal. Selanjutnya mengenai kendala yang terdapat dalam PTMt terutama muatan IPA banyak materi yang belum tuntas disampaikan. Sehingga untuk materi yang belum tuntas, maka disampaikan secara daring (online) seperti penggunaan $e$ learning. Kemudian penilaian dilakukan setiap hari oleh guru setelah peserta didik mengumpulkan tugas. Langkah ini dilakukan karena pembelajaran dilakukan secara terbatas.

\section{Responden (SS) SD Inpres 44 Kabupaten Sorong}

Berdasarkan hasil wawancara dengan responden (SS) mengenai persepsi guru tentang implementasi pembelajaran tatap muka terbatas di SD Inpres 44 Kabupaten Sorong menyatakan bahwa, PTMt dapat dilakukan sesuai dengan aturan pemerintah, melalui sistem block atau sistem shieft. Persepsi guru mengenai cakupan materi IPA menyatakan bahwa tidak semua materi dapat tersampaikan dengan maksimal, terutama muatan IPA yang berkaitan dengan praktek. Kemudian perencanaan pembelajaran seperti RPP dan bahan ajar sudah disiapkan sebelum pembelajaran berlangsung, isi dari RPP dan bahan ajar menyesuaikan dengan waktu yang sudah ditentukan dalam PTMt.

Adanya keterbatasan PTMt pada sekolah tersebut terutama muatan IPA kelas $\mathrm{V}$, maka guru/wali kelas memberikan modul dan tugas praktek yang dikerjakan dirumah. Harapannya dengan adanya langkah tersebut maka materi IPA dapat tersampaikan dengan maksimal kepada peserta didik. Berikutnya mengenai kendala yang dihadapi guru yakni harus menggunkan berbagai metode ataupun model yang lebih kreatif dan inovatif agar peserta didik lebih mudah untuk memahami materi IPA yang disampaikan oleh guru. Kemudian, penilaian dilaksanakan secara langsung (test lisan) dan secara tertulis (pemberian tugas) dikarenakan waktu 
pembelajaran sangatlah terbatas.

\section{Responden (Kr) SD Inpres 46 Kabupaten Sorong}

Berdasarkan hasil wawancara dengan responden $(\mathrm{Kr})$ mengenai persepsi guru tentang implementasi pembelajaran tatap muka terbatas di SD Inpres 46 Kabupaten Sorong menyatakan bahwa PTMt menyesuaikan dengan waktu dan keadaan yang ada selama pembelajaran tatap muka terbatas. Sesuai dengan peraturan pemerintah tepatnya surat edaran bupati mengenai PTMt, yang diatur dengan sistem block atau sistem Shieft dengan durasi waktu PTMt selama 3 jam. Selanjutnya perencanaan pembelajaran berupa RPP dan bahan ajar sudah disiapkan sebelum PTMt berlangsung walaupun kegiatan inti singkat, karena kembali menyesuaikan waktu yang sudah ditentukan dalam PTMt.

Persepsi responden $(\mathrm{Kr})$ mengenai cakupan materi IPA yang diberikan kepada peserta didik selama PTMt. Pembelajaran pada muatan IPA tetap dapat dilaksanakan, begitu juga pada materi yang terdapat prakteknya. Akan tetapi praktek yang disampaikan dan dilakukan oleh peserta didik adalah praktek yang mudah dikerjakan dirumah. Pemberian LKPD atau langkahlangkah praktikum dijadikan acuan oleh peserta didik untuk mengerjakan praktikum sesuai dengan contoh yang telah dipaparkan oleh guru disekolah. Selanjutnya perspsi responden $(\mathrm{Kr})$ mengenai kendala yang terdapat dalam PTMt yaitu mengenai ruang dan waktu yang terbatas. Kedua, sarana dan prasarana yang belum memadai berkaitan dengn leptop dan pulsa. Sehingga menjadi kendala yang dapat menghambat proses pembelajaran di sekolah atau di rumah. Berikutnya penilaian dilakukan dalam bentuk teori dan praktek, disesuaikan dengan situasi dan kondisi yang ada walupun ketercapaiannya tidak maksimal akibat pandemi.

\section{Responden (IA) SD Muhammadiyah Majaran Kab. Sorong}

Berdasarkan hasil wawancara dengan responden (IA) mengenai persepsi guru tentang implementasi pembelajaran tatap muka terbatas di SD Muhammadiyah Majaran Kabupaten Sorong menyatakan bahwa implentasi tatap muka terbatas dilakukan sistem shieft dan waktunya tetap disesuiakan dengan aturan dengan durasi PTMt 3 jam. Selanjutnya perencanaan pembelaran berupa RPP dan bahan ajar telah disiapkan dan disesuaikan dengan ketentuan PTMt. Persepsi responden (IA) mengenai cakupan materi IPA yang diberikan kepada peserta didik selama PTMt yaitu cakupan materi IPA yang diterapkan menggunakan modul yang sudah dirancang khusus untuk PTMt juga dipadukan dengan MBP yang digunakan sebelum pandemi covid-19. Selain itu, mengambil contoh video pembelajaran yang ada di Youtube untuk memudahkan peserta didik dalam memahami materi yang sedang dipelajari.

Selanjutnya persepsi responden (IA) mengenai kendala yang dialami selama PTMt adalah waktu, karena dibatasi sesuai dengan peraturan yang berlaku. Jadi ketika guru mengajarkan materi kepada peserta didik, tidak bisa seperti biasanya yang memiliki waktu lebih banyak. Penggunakan modul dan bantuan dari platform yang ada seperti Youtube, google meet dll, membantu peserta didik belajar ketika di rumah. Berikutnya selama PTMt berlangsung penilaian dilakukan setelah peserta didik mengumpulkan tugas yang telah diberikan.

Pembahasan ini mendeskripsikan bahwa berdasarkan analisis persepsi guru mengenai PTMt dimasa pandemi Covid-19, bahwa kebijakan PTMt di SD Gugus I 
Salawati Kabupaten Sorong, yang terdiri dari 4 sekolah diantaranya SD Inpres 35 Kabupaten Sorong, SD Inpres 44 kabupaten Sorong, SD Inpres 46 Kabupaten Sorong dan SD Muhammadiyah Majaran Kabupaten Sorong dapat dilaksanakan di sekolah sesuai kebijakan pemerintah melalui SKB 4 menteri dan surat edaran bupati Sorong dengan sistem blok atau shieft. Pembelajaran yang berlangsung harus sesuai dengan ketentuan protokol kesehatan, menjalin komunikasi dengan stakeholder (komite sekolah, pemeritah, puskesmas) melibatkan satgas, juknis, SOP yang jelas, hal ini didukung oleh penelitian Nisa, S., dan Haryanto, A., (2020). Beberapa diantaranya guru telah mendapatkan bimbingan dari kepala sekolah untuk menerapkan PTMt. Guru menyatakan tidak merasa keberatan untuk menerapkan PTMt, karena sebelumnya guru hanya dapat memberikan materi pembelajaran secara daring tanpa tatap muka secara langsung. Bahkan beberapa kelas ada yang harus diliburkan sementara sebelum adanya pembelajaran secara daring.

Perencanaan PTMt disesuaikan dengan kondisi dimasa pandemi yang dilakukan secara terbatas dan durasi yang sudah ditetapkan. Perencanaan PTMt diantaranya berupa RPP, menyiapkan bahan materi, menentukan media pembelajaran menyesuaikan dengan kondisi dan durasi yang sudah ditetapkan dengan durasi PTMt selama 3 jam dengan 1 hari maksimal 2 mata pelajaran. Pembelajaran tatap muka terbatas menjadi alternatif pembelajaran pada masa pandemi Covid-19, dimana waktu tatap muka dikurangi tetapi dikombinasikan dengan pembelajaran online (Supriatna, 2021). Sasaran yang ingin dicapai adalah agar kompetensi peserta didik tetap terjaga dan target pembelajaran harus tercapai, sehingga memerlukan kesiapan sarana dan prasarana.
Penyampaian materi selama proses pembelajaran dimasa pandemi covid-19 guru dapat melakukan inovasi menggunakan media pembelajaran yang telah tersedia saat ini baik secara online maupun offline (Sunarti, 2020).

Adanya pelaksanaan PTMt ini membawa angin segar bagi guru dan peserta didik, karena setidaknya guru dapat melakukan tatap muka dengan peserta didik walaupun secara terbatas. Hal ini juga yang dirasakan oleh peserta didik. Berkaitan dengan muatan IPA proses PTMt memudahkan peserta didik dalam belajar. Setidaknya peserta didik dapat menerima materi yang sampaikan secara langsung, walaupun dengan waktu yang terbatas. Selain PTMt yang berlangsung disekolah, guru memaksimalkan penggunaan teknologi untuk memudahkan proses pembelajaran secara daring/luring. Perkembangan teknologi telah memungkinkan untuk mengadaptasi pedagogik pengajaran yang efektif dalam memfasilitasi penyampaian pengetahuan (Guraya, 2020). Penyampaian materi pembelajaran harus disampaikan dengan baik kepada peserta didik agar mereka dapat beradaptasi dengan kebiasaan baru apabila Sedangkan kini harus kembali ke sekolah dengan metode pembelajaran baru dan harus mengikuti protokol kesehatan. Selain peserta didik, guru perlu menyesuaikan diri dan mengelola kesgiatan pembelajaran secara offline dengan baik agar target materi pembelajaran terutama pada muatan IPA tercapai.

Tahap evaluasi terdapat penilaian guna mengukur tingkat kemampuan peserta didik. Penilaian yang guru lakukan dalam PTMt, dilakukan setelah peserta didik mengumpulkan tugas yang sudah diberikan baik itu teori maupun praktek. Penilaian secara teori dan praktek dapat membantu 
guru dalam mengevaluasi proses pembelajaran, metode pembelajaran, strategi pembelajaran serta sejauh mana keberhasilan selama dilaksankannya PTMt. Melalui cara seperti ini guru dapat mengetahui dibagian sebelah mana siswa kurang memahami materi, dan dapat memberikan Penilaian dalam bentuk teori dan praktek, disesuaikan dengan situasi dan kondisi yang ada walupun ketercapaiannya tidak maksimal akibat pandemi.

\section{KESIMPULAN}

Pelaksanaan PTMt di SD Gugus I Salawati Kabupaten Sorong, yang terdiri dari 4 sekolah diantaranya SD Inpres 35 Kabupaten Sorong, SD Inpres 44 kabupaten Sorong, SD Inpres 46 Kabupaten Sorong dan SD Muhammadiyah Majaran Kabupaten Sorong disesuaikan dengan kebijakan pemeritah melalui SKB 4 menteri dan surat edaran bupati sorong tentang kegiatan belajar mengajar tahun pelajaran 2021/2022, yaitu dengan menggunakan sistem blok atau sistem shieft dengan durasi PTMt selama 3 jam dengan 1 hari maksimal 2 mata pelajaran. Perencanaan pembelajaranpun disesuaikan dengan kondisi dimasa pandemi yang dilakukan secara terbatas dan durasi yang sudah ditetapkan. Guru memberikan penjabaran materi sesingkat dan sesederhana mungkin agar peserta didik dapat dengan mudah memahami materi yang disampaikan. Guru memberikan tugas teori maupun praktek kepada peserta didik kemudian peserta didik mengumpulkan kepada guru. Penilaian yang guru lakukan dalam PTMt, dilakukan setelah peserta didik mengumpulkan tugas yang sudah diberikan baik itu teori maupun praktek.

\section{DAFTAR RUJUKAN}

Aan Hasanah. (2014). Pengembangan Profesi Guru. Bandung: CV Pustaka
Setia.

Ahmad Susanto. (2013). Teori Belajar dan Pembelajaran di Sekolah Dasar. Jakarta: Kencana Predamedia Group.

Alizamar, C. (2016). Psikologi Persepsi dan Desain Informasi; Sebuah Kajian Psikologi Persepsi dan Persepsi Kognitif untuk didikan. Yogyakarta: Media Akademi.

Aly, Abdullah \& Eny Rahma. (2010). Ilmu Alamiah Dasar. Jakarta: Bumi Aksara.

Anshori, Sodiq. (2014). Pembelajaran Tematik (Tematik Integrative) Mata Pelajaran IPA pada Kurikulum 2013. Jurnal Ilmiah PGSD. 2, 42.

Asmani, M. Jamal. (2014). 7 Tips Aplikasi PAKEM [Pembelajaran Aktif, Kreatif, Efektif, dan Menyenangkan]. Jogjakarta: Diva Press.

Assidiqi, M. H., Sumami, W. (2020). Pemanfaatan Platform Digital di Masa Pandemi Covid-19. Seminar Nasional Pascasarjana UNNES

Dewi, W. A. F. (2020). Dampak Covid-19 terhadap Implementasi Pembelajaran Daring di Sekolah Dasar. Jurnal Ilmu Pendidikan, 2(1), 55-61

Djamarah, Syaiful Bahri. (2015). Psikologi Belajar. Jakarta: Rineka Cipta.

Fadila, Dewi \& Sari Lestari Zainal Ridho. (2013). Perilaku Konsumen. Palembang: Citrabooks Indonesia.

Guraya, S. (2020, August 1). Combanting the Covid-19 Outbreak With A TeknologiDrivent E-Flipped Classroom Model Off Educational Tranformation. Journal Of Taibah University Medical Scinces, Vol. 15, PP. 253-254. Elsevier B. V.

Hanurawan, Fattah. (2012). Psikologi Sosial. Bandung: PT Remaja Rosdakarya Offset.

Hariyanto, Dita Dityas., Dewi, Erti Ikhtiarini., \& Aini, Latifa. (2014). Hubungan Persepsi Tentang Kesesuaian Harapan Orang Tua dengan Diri dalam Pilihan Studi Lanjut dengan Tingkat Stress pada Siswa Kelas XII di Kabupaten Jember. E-Jurnal Pustaka Kesehatan Online. 
Kompri. (2015). Motivasi Pembelajaran Persfektif Global. Bandung: PT Remaja Rosdakarya Offset.

Mega Wati. (2020). "Nadiem: Keputusan Belajar Tatap Muka Ada Di Tangan Pemda", https://teropongnews.com/2021/02/nadiem -keputusan-belajar-tatap-muka-ada-ditangan-pemda, diakses pada 15 Juni 2021 pukul 11.50.

Mendikbud. 2020. "Mendikbud Terbitkan SE tentang Pelaksanaan Pendidikan dalamMasadaruratCovid19",https://ke mdikbud.go.id/main/blog/2020/03/mendik bud-terbitkan-se-tentang-pelaksanaanpendidikan-dalam-masa-darurat-covid19, diakses pada 14 April 2021 pukul 10.15 .

Nasional, D. P. (2005). Undang-Undang Republik Indonesia No. 20 Tahun 2005 Tentang Guru dan Dosen. Jakarta: Depdiknas RI.

Nawawi, 2015. Manajemen Sumber daya Manusia, Universitas Gajah Mada, Yogyakarta.

Nupita, E. (2013). Penerapan Model Pembelajaran Penemuan Terbimbing Untuk Meningkatkan Hasil Belajar dan Keterampilan Pemecahan Masalah IPA Pada Siswa Kelas V Sekolah Dasar. Jurnal Penelitian PGSD.

Ribka Putri Agustami, W. S. (2017). Persepsi Guru dan Siswa Terhadap Pembelajaran IPA Terpadu Serta Implikasinya di SMP. Journal of Innovative Science Education, 6 (1).

Sagala, S. (2011). Konsep dan Makna Pembelajaran. Bandung: Alfabeta.

Samidi., dan Istarani. (2016). Kompetensi \& Profesionalisme Guru Ilmu Pengetahuan Alam (IPA) dan Matematika. Medan: Larispa.

Siti Faizatun Nissa, A. H. (2020). Implementasi Pembelajaran Tatap Muka Di Masa Pandemi Covid-19. Jurnal IKA : IKATAN ALUMNI PGSD UNARS VOL 8 No. 2.
Sobron A.N, B. R. (2019). Persepsi Siswa Dalam Studi Pengaruh Daring Learning Terhadap Minat Belajar Siswa. Jurnal Pendidikan Islam san Multikuturalisme, Vol. 1 No. 2.

Sobron A.N, B. R. (2019). Persepsi Siswa Dalam Studi Pengaruh Daring Learning Terhadap Minat Belajar Siswa. Jurnal Pendidikan Islam san Multikuturalisme, Vol. 1 No. 2.

Sriyanti, Lilik. (2013). Psikologi Belajar. Yogyakarta: Ombak.

Sonia Anggianita, Y. M. (2020). Persepsi Guru Terhadap Pembelajaran Daring di Sekolah Dasar Negeri 013 Kumantan. Journal of Education Research, 1 (2) 177-182.

Sugiyono. (2016). Metode Penelitian Kuantitatif, Kualitatif dan $R \& D$. Bandung: PT Alfabet.

Supriatna, U. (2021). Kompetensi Guru Memenfaatkan Teknologi Informasi dan Komunikasi Dalam Mengembangkan Media Pembelajaran Online. Edumaspul: Journal Pendidikan, 5 (1) 214-221

Tanuwijaya, N.S. dan Tambunan, W., (2021). Alternatif Solusi Model Pembelajaran Untuk Mengatasi Resiko Penurunan Capaian Belajar Dalam Pembelajaran Tatap Muka Terbatas di Masa Pandemi Covid-19 (Studi Kasus Analisis Kebijakan Pendidikan). Journal Manajemen Pendidikan. ISSN 2301-5594. 10 (02)

Trianto. (2015). Model Pembelajaran Terpadu. Jakarta: PT Bumi Aksara

Wang, Y. (2007). On the Cognitive Processes of Human Perception with Emotions, Motivations, and Attitudes. International Journal of Cognitive Informations and Natural Intelligence (IJCNI).

Yin, R. K. (2015). Studi Kasus: Desain dan Metode. Jakarta: Rajawali Pers. 